\title{
correspondence
}

\section{Moon matters}

SIR,-If your editorial "Bringing men to the Moon" (October 25) had been that of any journal other than Nature, we should have ignored it. In view of your prestige and of your great influence within the scientific community, we have decided to answer it.

You have sought to discredit this conference on a number of counts. You write, in reference to a previous conference, "while the scientists thought it silly, the philosophers took it all very seriously". In fact, at this meeting, only two of the 20 scholars were philosophers.

The purpose of the International Conference on the Unity of the Sciences is to further the field of communication between science and philosophy. The response of scientists to matters are naturally different from that of the philosophers. This indicates ignorance of modern philosophy.

Your sarcastic reference to the Second Conference in Tokyo is most surprising, since the conference itself was a success. Proceedings are available to those interested.

As to the 'messages of congratulation' by Nobel Laureates--messages of good-will, you must admit, can only be sent by the free will of those who send them. The manner of your reference to this indicates a prejudice. To write in this vein is nothing less than to despise a person, whoever he may be.

You attribute the most sinister possible motives to the founder of the organisation under whose auspices this conference is taking place. Surely $\mathrm{Mr}$ Moon, as any other philosopher of science living in the free world, is quite free to be devoted to any philosophy that he may choose for himself. Would it be unnatural to think that the initiator of the International Conference holds a specific point of view.

The aims, purposes and the nature of the Foundation, as admirable as they are, as set forth in the conference brochure, were clear and precise. Unfortunately, however, your statements about it seem to suggest that you had never read it.

You say that not all the advisers were very pleased to have their names used in this way. Basically, we have no intention of using the names of eminent scholars for purposes contrary to their own wishes. As you may know one person who agreed early on to serve as an adviser subsequently chose to withdraw for his own reasons. As to our other advisers, both in the United Kingdom and internationally, they contributed greatly to the preparations of this significant event.

A feature of your editorial, unfortunately, is that general statements, even parts based on objective fact, demonstrate the prejudice and the apparent ill-intentions of the writer.

The list of participants you refer to was printed several months ago and included several names among which were firm acceptances as well as tentative ones. You have used this document to make allegations of improper conference management.

In reply to your enquiry: as founder of the Foundation under whose auspices this conference is taking place, $\mathrm{Mr}$ Moon has a right to be present and, contrary to your suggestion, he will, I understand, actually deliver the Founder's address.

It is suggested that in future you avail yourself of a more rigorous methodology for the purpose of discrediting those scientific enterprises of which you disapprove.

Morals are but an attempt to examine goals. And how can any behaviour be judged scientifically except in terms of its ability to achieve a goal? Any other criterion you must admit can only be purely subjective.

It may be true that there is, at present, no scientific methodology for the examination of basic goals, but the fault is surely with modern science for not having developed it. For until it is developed, scientists must accept their incapacity to examine the very assumptions on which their work is based. They must content themselves with doing things, without ever knowing why they should be done.

Contrary to what you intimate, we have no ideological bias. A number of scientists from the Communist countries were invited to this conference but, as it happened, could not attend.

It is suggested by way of conclusion that you ought to have taken the trouble to meet the person of central responsibility for the activity in question rather than questioning a subordinate employee whose knowledge may well be limited and even inaccurate.

In this case, I encourage you to accept the invitation extended to you in June this year, and to attend the Third International Conference on the
Unity of the Sciences, in order that you may evaluate its true value and import first hand, rather than relying on second-hand and perhaps unreliable sources.

In your allusion to 'their Boeing complex and their propensity to amateur philosophising', in reference to the eminent scientists, you have intentionally or unintentionally demonstrated your contempt and disrespect for those "deeply concerned scholars" who are willing to contribute to the urgent issues of the unity of science and the relation between science and morals.

\section{ICUS, London SWI, UK}

\section{P. Brian WiJeratne}

The 'subordinate employee whose knowledge may well be limited and even inaccurate' was the 'Chief Public Relations Officer.'-ED.

\section{Chemicals and cancer}

SIR,-Your October 11 issue summarised some of the issues in the Aldrin and Dieldrin Suspension Hearing.

I was attributed-incorrectly-with five criteria which must be met before there is sufficient evidence of human carcinogenicity. These criteria appeared in the Administrator's Opinion of October 1, and are not quoted from any statement made by me. An EPA attorney and an EPA witness caricatured my opinions by suggesting that I would only recommend the removal of a product from the market after cases of human cancer had occurred. This is not-and never has been-my opinion. To avoid any misunderstanding I submitted an additional statement on this topic to the hearing record on September 11, in which I also indicated that their belief was apparently based on my answer to the question whether we would take dieldrin off the market if human cancer cases occurred.

My affirmative answer did not imply that I would not give advice to that effect at an earlier stage. It is not my position that we must wait for human cancer before removing a product from the market.

I was, therefore, surprised to see in the Administrator's Opinion that my "demands are practically impossible to meet".

Tunstall Laboratory, Sittingbourne, Kent, UK 